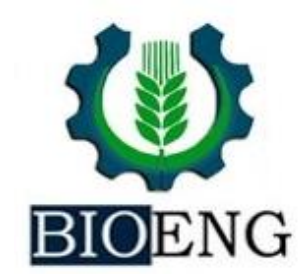

\title{
BIOGAS PRODUCTION FROM DAIRY CATTLE MANURE SUBJECTED TO CHEMICAL PRE-TREATMENT
}

\author{
W.R. Andrade ${ }^{1 *}$, T.M.B. Santos ${ }^{2}$, L.D.O. Arruda ${ }^{2}$, \\ E.M. Rosa ${ }^{2}$, N. Cappi ${ }^{2}$
}

${ }^{1}$ UFV - Federal University of Viçosa, Department of Agricultural Engineering, Campus of Viçosa-MG, Brazil.

${ }^{2}$ UEMS - State University of Mato Grosso do Sul, Department of Animal Science, Campus of Aquidauana - MS, Brazil.

Article history: Received 26 January 2018; Received in revised form 16 March 2018; Accepted 17 March 2018; Available online 31 March 2018.

\begin{abstract}
Alkali and acid chemical pre-treatment for lignocellulosic biomass can affect the amount of energy harvested from it during the anaerobic digestion process. This study aimed to assess the biogas production of dairy cattle manure subjected to acid and alkaline pre-treatment. This assay was performed in two phases, which consisted of 10 days of pre-treatment and 120 days of anaerobic digestion. The substrates for pre-treatment and anaerobic digestion phase were calculated to attain 5\% of total solids (TS). Pre-treatment phase was conducted during 10 days and the following experimental treatments were used: Control (Water); $2.5 \%$ of hydrochloric acid (HCl-2.5\%), 2.5\% of dolomite limestone (DI-2.5\%), 5.0\% of hydrochloric acid (HCl$5.0 \%$ ) and $5.0 \%$ of dolomite limestone (DI-5.0\%). After this phase, $\mathrm{pH}$ of all substrates had their values corrected to the start of the anaerobic digestion phase. Higher volatile solids reduction was attained by treatment Dl-5.0\% whose biogas production and biogas yield per $\mathrm{kg}$ of waste was significantly higher compared to control treatment. Cattle manure pre-treated with $5.0 \%$ of dolomite limestone for 10 days incremented the biogas yield per $\mathrm{kg}$ of waste.
\end{abstract}

Keywords: Dolomite limestone. Hydrochloric acid. Organic matter

\section{PRODUÇÃO DE BIOGÁS POR DEJETO DE BOVINOS LEITEIROS SUBMETIDOS A PRÉ-TRATAMENTO QUÍMICO}

\section{RESUMO}

O uso de pré-tratamentos ácidos ou alcalinos em biomassa lignocelulósica pode influenciar na quantidade de biogás e energia obtida durante o processo de digestão anaeróbia. Objetivou-se avaliar a produção de biogás de dejetos de bovinos leiteiros submetidos a pré-tratamento ácido e alcalino. Foram conduzidas duas fases experimentais, que consistiram em 10 dias de pré-tratamento e 120 dias de digestão anaeróbia. Os substratos utilizados para o prétratamento e abastecimento dos digestores foram calculados para que obtivessem $5 \%$ de sólidos totais (ST). A fase de pré-tratamento foi conduzida por 10 dias e, para tanto foram utilizados os seguintes tratamentos experimentais: controle (água) ou CT; $2.5 \%$ de ácido hidroclorídrico (HCl-2.5\%); $2.5 \%$ de calcário dolomítico (DI-2.5\%); $5.0 \%$ de ácido hidroclorídrico ( $\mathrm{HCl}-5.0 \%$ ) e $5.0 \%$ de calcário dolomítico (DI-5.0\%). Conseguinte a essa fase o substrato teve seu pH corrigido para o início da fase de digestão anaeróbia em batelada. Maiores reduções de sólidos voláteis foi obtido pelo tratamento DI-5.0\% cujos rendimentos de biogás por kg de dejetos foram significativamente superiores ao observado pelo tratamento

\footnotetext{
*willian_rufino_andrade@ hotmail.com
} 
controle. Dejetos de bovinos pré-tratados com calcário dolomítico a 5.0\% durante 10 dias promove aumento no rendimento de biogás por $\mathrm{kg}$ de dejeto.

Palavras-chaves: Ácido hidroclorídrico. Calcário dolomítico. Matéria orgânica.

\section{INTRODUCTION}

Anaerobic digestion has been widely used as a wastewater treatment method in livestock production systems mainly due to growing environmental problems such as air, soil and water pollution caused by gaseous emissions and uncontrolled disposal of waste. Nevertheless, the biomass energy harnessing has been one of the main purpose when it comes to biomass treatment. Improper waste disposal has also led to the spread of pathogenic microorganisms and constitutes a severe health hazard (ČATER et al. 2014).

During the process of anaerobic digestion (AD), microorganism breakdown biomass in absence of oxygen transforming it in a mixture of gases that typically consist in $60-65 \%$ of methane $\left(\mathrm{CH}_{4}\right), 35$ $40 \%$ of carbon dioxide $\left(\mathrm{CO}_{2}\right)$, and traces of ammonia $\left(\mathrm{NH}_{3}\right)$, hydrogen sulfide $\left(\mathrm{H}_{2} \mathrm{~S}\right)$ and nitrogen $\left(\mathrm{N}_{2}\right)$ (TAUSEEF et al. 2013). Due to its combustion properties, methane produced during the anaerobic digestion process can be harvested for energy supply and the effluent used as a crop fertilizer (SURENDRA et al. 2014 \& ENNOURI et al. 2016).

In rural areas, especially in developing countries such as Brazil, (PINAS et al. 2018); Chile (RODRIGUEZ-MONROY et al. 2018); China (WANG et al. 2017); India (RAYCHAUDHURI \& GHOSH, 2016) and Pakistan (MIRZA et al. 2008) there is a great variety of lignocellulosic biomass that has reasonable potential for energy production by means anaerobic digestion, for instance cattle manure. Nevertheless, cattle manure can yield low biogas production since it has lignocellulosic structures of low degradability rate (VANHOLME et al. 2010). These structures are basically compound by cellulose, hemicellulose and lignin
(CARRERE et al. 2016), this last, branch biopolymers of complex phenolic nature that confers resistance to the vegetal cell has low degradability rate by enzymatic and microbial action (ANGELIDAKI \& AHRING, 2000).

Ruminant animals are known for their ability to use efficiently the diet. Most of the fiber present in the manure of ruminant, for instance, has already undergone breakdown while passing through the animal's digestive tract. Nonetheless, the end products from digestive tract of ruminants may contain significant amount of precursors that can be harnessed for energy (SAWATDEENARUNAT et al. 2015). According to Saady \& Masse (2016) about $50 \%$ of the volatile solid present on dairy cattle manure are biodegradable.

It has been suggested that alkali and/or acid chemical pre-treatment of lignocellulosic waste can affect the amount of biogas energy harvested from it during the anaerobic digestion process (KUMAR et al. 2009; BRUNI et al. 2010; ZHENG et al. 2014; CARRERE et al. 2016; ENOURI et al. 2016). According to Mao et al. (2015), alkali treatment breaks the link between lignin and polysaccharides causing lignocellulose material to swell while disrupting branched polymer bonds. This results in an increased surface area for anaerobic microorganism breaking down activity. It is further argued that acid pretreatment causes a disruption of covalent and hydrogen bonds, and Van der Waals forces, which increases the solubility of hemicelluloses by reducing cellulose and hydrolyzing hemicellulose into monosaccharides (PANEPINTO \& GENON, 2016).

Despite of many results in the literature regarding anaerobic digestion of pre-treated biomass, few researchers such 
as Bruni et al. (2010) and Andrade et al. (2016 b) have worked with anaerobic digestion of chemical pre-treated animal manure. Moreover, as mentioned by Xavier et al. (2016), AD system using cattle manure as substrate might not cover the costs of the implantation of an anaerobic reactor system due to the fact that cattle manure has a very high lignified fraction which results in lower biogas and methane yield as compared to manure from other domestic species. Thus, techniques

\section{MATERIAL AND METHODS}

The anaerobic digestion assay was carried out in the laboratory of Biomass and Water Quality at State University of Mato Grosso do Sul located in Aquidauana - MS, Brazil (Latitude 202' S; Longitude $\left.55^{\circ} 48^{\prime} \mathrm{W}\right)$. The experiment was conducted during the rainy season, with an average temperature of $29.02^{\circ} \mathrm{C}$.

This study was performed in two phases, which consisted of 10 days of pretreatment and 120 days of anaerobic digestion. The substrates for pre-treatment and anaerobic digestion phase were (such as anaerobic codigestion, mechanical, enzymatic and chemical pretreatment) that promote improvement in biogas yield should be adopted in order to make the $\mathrm{AD}$ process with cattle manure feasible.

Then, considering all the reviewed content, this study aimed to assess the biogas production of dairy cattle manure (CM) subjected to acid and alkaline pretreatment. calculated to attain $5 \%$ of total solids (TS) based on dry matter (DM) of the manure of $17.01 \%$. Manure used to perform the pretreatment and fed the batch digesters were collected from Pantaneira breed lactating cows kept in extensive system grazing based on Mombaça forage (Panicum maximum). At the time of milking manure was collected by scraping the floor.

To conduct the first assay, it was used plastic vessels of 3 liters each to perform the pre-treatment as seen in the schematic representation in the Figure 1.

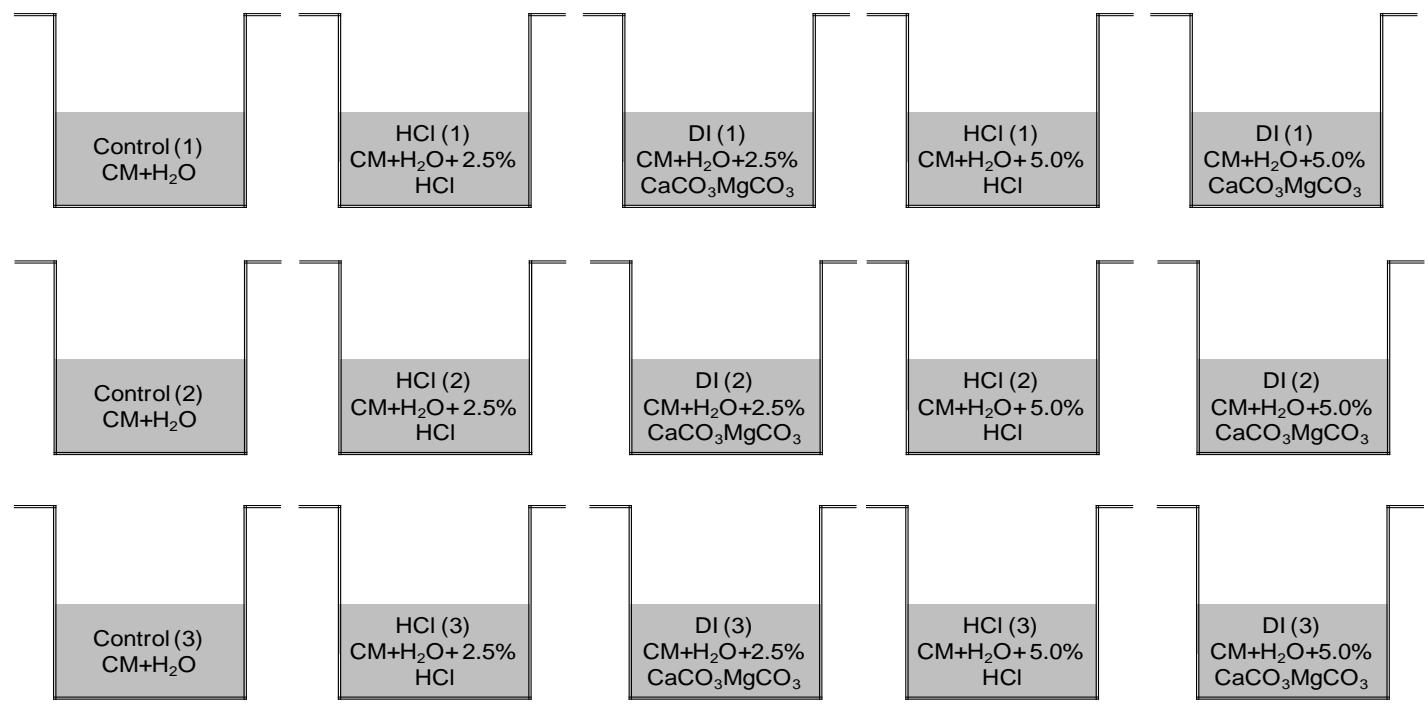

Figure 1. Schematic representation of the chemical pre-treatment phase in vessels of 3 liters. CM- Cattle manure; $\mathrm{H}_{2} \mathrm{O}$ - Water; $\mathrm{HCl}$ - Hydrochloric acid; DI and $\mathrm{CaCO}_{3} \mathrm{MgCO}_{3}-$ Dolomite limestone.

The experimental treatments were: Control (Water) or CT; $2.5 \%$ of hydrochloric acid $(\mathrm{HCl})$ (weight/volume);
$2.5 \%$ of dolomite limestone (D1) (weight/volume); $5.0 \%$ of $\mathrm{HCl}$ (weight/volume) and $5.0 \%$ of $\mathrm{Dl}$ 
(weight/volume). The concentrations of each chemical was previous study in preliminary assay using inclusions of 0 ; 2,$5 ; 5,0$ and $7,5 \%$ in order to assess the most adequate amount of acid and alkaline treatment to be added into the substrate (ANDRADE et al. 2016 a).

To perform the AD, it was used fifteen laboratory-scale batch digester of 2 liters capacity. They were composed of two distinct parts as seen in the Figure 2, a fermentative chamber and a gasometer. Each fermentation chamber had a hose barb connected to a hose through which gas was collected. Both components of the anaerobic digester were made by cylindrical PVC. The gasometer was comprised by an inner and outer PVC cylinder, whose main purpose was to store and allow the quantification of the gas produced through the displacement of the inner PVC. All digesters were kept in environment temperature housed from solar light and rain through the study period.

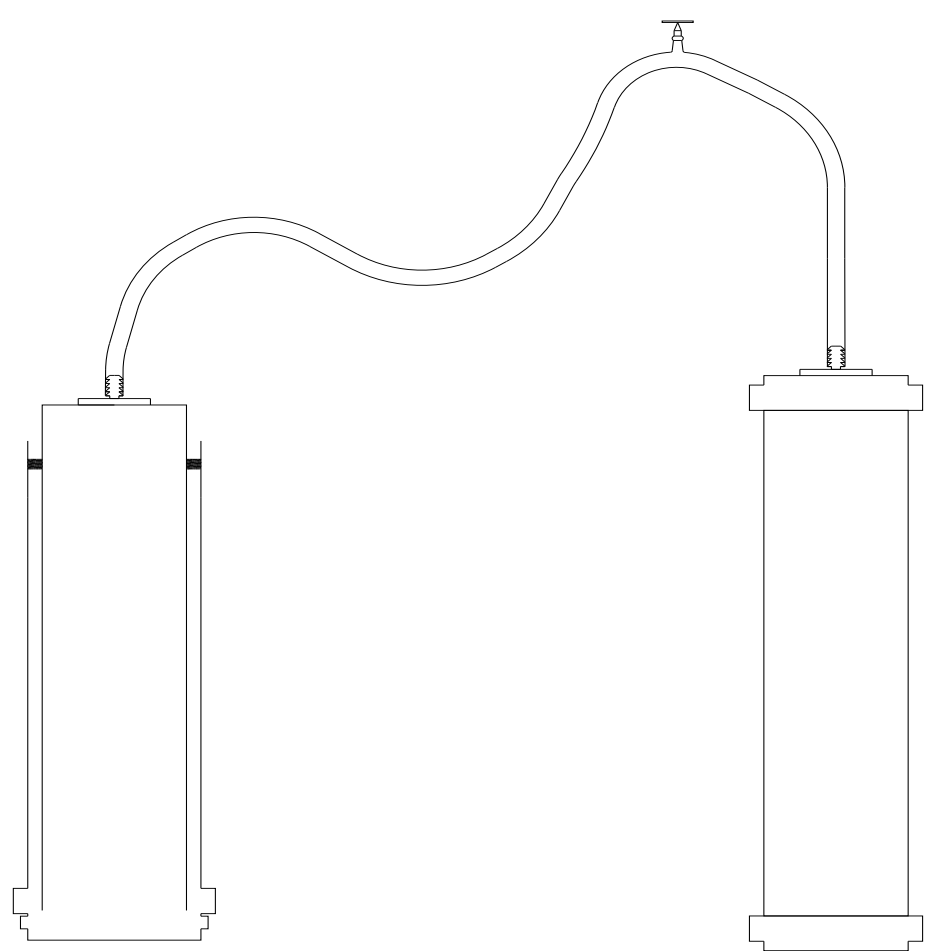

Figure 2. Graphic representation of the batch anaerobic reactors used in this study which is comprised by the Gasometer connected to a fermentation chamber through a silicone pipe with a discharge valve. Source: Author

All the components used to prepare the substrate for pre-treatment and to feed the anaerobic reactors are expressed in kilograms on the Table 1.

Table 1. Components of the substrates used to feed the batch digesters.

\begin{tabular}{lccc}
\hline Treatments & Water & Manure & Chemical \\
\hline Control & 1.060 & 0.440 & - \\
Hydrochloric acid $-2.5 \%$ & 1.020 & 0.440 & 0.037 \\
Dolomite limestone $-2.5 \%$ & 1.020 & 0.440 & 0.037 \\
Hydrochloric acid $-5.0 \%$ & 0.985 & 0.440 & 0.075 \\
Dolomite limestone $-5.0 \%$ & 0.985 & 0.440 & 0.075 \\
\hline
\end{tabular}

$\mathrm{HCl}$ was measured by volumetric pipet and the Dolomite limestone was weighted using an analytic weighing machine. The chemical reagents were then added and homogenized in their respective 
substrate simultaneously until complete dilution.

After 10 days of resting in a pretreatment, all substrate had its $\mathrm{pH}$ assessed and if needed corrected to neutral condition by means $0.5 \%$ addition of sodium bicarbonate $\left(\mathrm{NaHCO}_{3}\right)$. After that, substrates were placed in the batch digesters, where they were kept in anaerobic condition for 120 days. Considering cattle manure a high lignified biomass which might take longer to be breakdown by microorganisms, a fermentation period of 120 days was adopted.

Determinations of TS and VS concentration were performed in the beginning of the assay and in the day 120 in which digesters were opened. Samples from each treatment was taken and submitted to $105^{\circ} \mathrm{C}$ in an oven during 24 hours to assess the TS, and VS were found by submitting samples in to the oven under $550^{\circ} \mathrm{C}$ for about 4 hours, following methodology described by APHA, AWWA, WPCF (2012).

In order to measure the volume of gas produced, a scale was used to get the displacement of the gas collector as pressure mounts the generated gas. The value was multiplied by the inner transversal section area of $0.007854 \mathrm{~m}^{2}$.

In order to correct the biogas volume at $1 \mathrm{~atm}$ and $25^{\circ} \mathrm{C}$, it was used an equation resulted from the combination of Boyle's and Gay-Lussac's law as described by Santos et al. (2016):

\section{RESULTS AND DISCUSSION}

Might be noticed that TS values ranged from 13.29 to $18.53 \%$, however, there was no statistical difference $(\mathrm{P}>0.05)$ for total solids reductions between all treatments compared to the control. When it comes to VS reduction it was possible to noticed statistical difference, revealing treatment Dl - 5.0\% with high VS reduction if compared to the control $(\mathrm{P}<0.05)$. This may be explained by the highest destruction of degradable components and biogas production attained
In which:

$$
\mathrm{V}_{0} \mathrm{P}_{0} / \mathrm{T}_{0}=\mathrm{V}_{1} \mathrm{P}_{1} / \mathrm{T}_{1}
$$

$\mathrm{V}_{0}=$ corrected biogas volume, $\mathrm{m}^{3}$;

$\mathrm{P}_{0}=$ corrected pressure of biogas, 10332.72 $\mathrm{mm}$ de $\mathrm{H}_{2} \mathrm{O}$;

$\mathrm{T}_{0}=$ Corrected temperature of biogas, 298.15 (Kelvins);

$\mathrm{V}_{1}=$ volume of biogas in the gasometer;

$\mathrm{P}_{1}=$ biogas pressure at the reading, $22 \mathrm{~mm}$ of water;

$\mathrm{T}_{1}=$ biogas temperature at reading $\mathrm{K}$.

Considering the atmospheric pressure in Aquidauana of $10293 \mathrm{~mm}$ of $\mathrm{H}_{2} \mathrm{O}$, we have as a result the following equation to the correction of biogas volume:

$$
\mathrm{V}_{0}=\left(\mathrm{V}_{1} / \mathrm{T}_{1}\right) * 297.6515
$$

To calculate the biogas yield was used data of daily biogas production of each digester and the amount of VS added. The results were expressed in $\mathrm{m}^{3}$ of biogas per $\mathrm{kg}$ of VS added.

The variables evaluated were TS and VS, biogas production, biogas yield $\left(\mathrm{m}^{3} / \mathrm{kg}\right.$ of $\left.\mathrm{VS}_{\text {added }}{ }^{-1}\right)$. A completely randomized design was adopted. Data from TS, VS, weekly biogas production, biogas yield per $\mathrm{kg}^{-1}$ of waste and per $\mathrm{kg} \mathrm{SV}_{\text {add }}{ }^{-1}$ were submitted to ANOVA using the software Speed Stat (CARVALHO \& MENDES, 2017), and when needed, the mean values were compared by Dunnet's test at $5 \%$ of probability.

by that treatment (Table 1) in which was used an alkaline pre-treatment. The VS reductions noticed on our experiment by the treatment that was subjected to $5.0 \%$ of dolomite limestone pre-treatment was higher to what was found by Dias et al. (2014) that reached $41.5 \%$ in VS reduction operating digester feed with liquid fraction of cattle manure; Moset et al. (2015) that attained $34.3 \%$ in VS reduction working with cattle manure subjected to mesophilic anaerobic digestion and Matos et al. (2017) 
who achieved VS reduction of $31 \%$ in a batch system digesting dairy cattle manure.

The higher destruction of volatile solids resulted in higher biogas production by the treatment $\mathrm{Dl}-5.0 \%$ as seen in the Table 2. The value attained by that treatment was statistically higher than that of the control. On the other hand, treatment Dl - $2.5 \%$ achieved lower biogas production $\left(\mathrm{m}^{3}\right)$ when compared to control. No statistical difference $(\mathrm{P}>0.05)$ was noticed for the other treatments $(\mathrm{HCl}-2.5$ and $\mathrm{HCl}$ - 5.0) compared to the control (Table 2).

Table 2. Average values of TS and VS reduction and biogas yield from batch digester fed with dairy cattle manure pre-treated in terms of $\mathrm{m}^{3} / \mathrm{kg}^{-1}$ of waste and $\mathrm{m}^{3} / \mathrm{kg}$ of VS add ${ }^{-1}$.

\begin{tabular}{lccccc}
\hline Treatments & $\begin{array}{c}\text { TS } \\
\text { Reduction } \\
(\%)\end{array}$ & $\begin{array}{c}\text { VS } \\
\text { Reduction } \\
(\%)\end{array}$ & $\begin{array}{c}\text { Weekly Biogas } \\
\text { production } \\
\left(\mathrm{m}^{3}\right)\end{array}$ & $\begin{array}{c}\text { Biogas yield } \\
\left(\mathrm{m}^{3} / \mathrm{kg}^{-1} \text { of }\right. \\
\text { waste })\end{array}$ & $\begin{array}{c}\text { Biogas } \\
\text { yield } \\
\left(\mathrm{m}^{3} / \mathrm{kg} \mathrm{SV}_{\text {add }}{ }^{-1}\right)\end{array}$ \\
\hline Control & 13.62 & 30.77 & 0.0175 & 0.0398 & 0.2710 \\
$\mathrm{HCl}-2.5 \%$ & $13.29^{\mathrm{ns}}$ & $32.55^{\mathrm{ns}}$ & $0.0151^{\mathrm{ns}}$ & $0.0345^{\mathrm{ns}}$ & $0.2377^{\mathrm{ns}}$ \\
$\mathrm{Dl}-2.5 \%$ & $18.53^{\mathrm{ns}}$ & $33.14^{\mathrm{ns}}$ & $0.0118^{*}$ & $0.0269^{*}$ & $0.2038^{\mathrm{ns}}$ \\
$\mathrm{HCl}-5.0 \%$ & $14.62^{\mathrm{ns}}$ & $31.24^{\mathrm{ns}}$ & $0.0180^{\mathrm{ns}}$ & $0.0409^{\mathrm{ns}}$ & $0.2845^{\mathrm{ns}}$ \\
$\mathrm{Dl}-5.0 \%$ & $16.44^{\mathrm{ns}}$ & $50.69^{*}$ & $0.0256^{*}$ & $0.0581^{*}$ & $0.4229^{\mathrm{ns}}$ \\
\hline${ }^{\mathrm{C}} \mathrm{CV}(\%)$ & 21.04 & 15.75 & 9.69 & 8.69 & 8.4 \\
\hline
\end{tabular}

${ }^{1}$ Coefficient of variation; Averages followed by * statistically differ from control treatment through Dunnet's test at 5\% of probability.

For biogas yield in terms of $\mathrm{m}^{3} / \mathrm{kg}^{-1}$ of waste it was found statistical difference for treatment $\mathrm{Dl}-2.5 \%$ and $\mathrm{Dl}-5.0 \%$ compared to the control $(\mathrm{P}<0.05)$. As seen in the Table 2 treatment $\mathrm{Dl}-2.5 \%$ achieved a lower performance $(0.0269$ $\mathrm{m}^{3} / \mathrm{kg}^{-1}$ of waste) than that of the control $\left(0.0398 \mathrm{~m}^{3} / \mathrm{kg}^{-1}\right.$ of waste $)$. In contrast, treatment Dl - 5.0\% attained the highest biogas yield in terms of $\mathrm{m}^{3} / \mathrm{kg}^{-1}$ of waste of 0.0581. Comparing the mean value achieved by treatment $\mathrm{Dl}-5.0 \%$ of 0.0581 to the control $\left(0.0447 \mathrm{~m}^{3}\right)$ it is possible to infer that the use of ten days of chemical pre-treatment was able to incremented the biogas yield in terms of $\mathrm{m}^{3} / \mathrm{kg}^{-1}$ of waste in about $31.6 \%$.

The findings in this study indicates that the use of $5.0 \%$ of dolomite limestone as chemical pre-treatment might represent an interesting improving in biogas yield per $\mathrm{kg}$ of waste. And the results might be explained by the fact that when alkaline pre-treatment is used in a lignocellulosic biomass it causes lignocellulosic material's disruption, leading an increased surface area for anaerobic microorganism to act (MAO et al. 2015). Besides, according to Carrere et al. (2016) alkaline pre-treatment acts solubilizing the hemicellulose and allows the preservation of easily soluble carbohydrates, which might be used as biogas precursor. Some authors have showed interesting results in anaerobic digestion of pre-treated lignocellulosic biomass using alkaline substances such as He et al. (2008), Bruni et al. (2010) and Andrade et al. (2016 b).

Stronger alkaline or acid pretreatments might be suitable to attain better results when it comes to increase the biogas yields since it promotes higher formation of components that are used as precursors for biogas production, such as, acetate which is used by methanogenic microorganism via acetotrophic path producing methane (TAUSEEF et al. 2013; CHOONG et al. 2016). However, the use of sodium hydroxide, potassium hydroxide and sulfuric acid, for instance, as stronger chemicals, can lead higher expense compared to the use of dolomite limestone, used in this essay. Therefore, when used chemical pre-treatment, it is noteworthy to consider the application cost of this technology because at the same time pre-treatment may promote a better biogas production by unit of waste added into the 
system, the chemical cost needs to be taken into account.

Despite of the fact that comparison of attained anaerobic digestion's data is quite questionable, specially because each study was conducted in a specific condition, should be highlighted that some data found on literature from anaerobic digestion assays without any pre-treatment are quite low compared to what was found in our study, and so, it confirmers that chemical pre-treatment may be suitable to improve biogas yield. Amaral et al. (2004) working with anaerobic digestion of dairy cattle manure in batch digester reached biogas yield of $0.024 \mathrm{~m}^{3} / \mathrm{kg}^{-1}$ of waste and Bertozzo, (2013) working with dairy cattle manure reached $0.016 \mathrm{~m}^{3} / \mathrm{kg}^{-1}$ of waste after 120 days of fermentation. That values were respectively 58.7 and $72.5 \%$ lower than the observed in our assay with dairy cattle manure pre-treated with $5.0 \%$ of dolomite limestone which reached 0.0581 $\mathrm{m}^{3} / \mathrm{kg}^{-1}$ of waste. Thus, it is indeed important to take into consideration the specific conditions in which each assay was carried out once some characteristic such as environmental temperature, digester's feeding substrate, hydraulic retention time, animal breed, animal feeding, substrate stirring, and others can definitely influence the final results.

In the conditions that this study was carried out, no statistical difference was revealed for biogas yield in terms of $\mathrm{m}^{3} / \mathrm{kg}$ of $\mathrm{VS}_{\text {added }}{ }^{-1}$ comparing all treatment to the control. The values ranged from 0.2028 to $0.4229 \mathrm{~m}^{3} / \mathrm{kg}$ of $\mathrm{VS}_{\text {added }}{ }^{-1}$.

However, comparing our data with what is found on the literature, apparently, the pre-treatment of dairy cattle manure with $5 \%$ of dolomite limestone contributed to increase the biogas yield in terms of VS added as seen in Table 3.

Table 3. Present study result data of biogas yield in $\mathrm{m}^{3} / \mathrm{kg}$ of $\mathrm{VS}_{\text {add }}{ }^{-1}$ as compared to literature data and its respective difference in $\%$ of the amount of biogas yield.

\begin{tabular}{cc}
\hline $\begin{array}{c}\text { Present study result } \\
\left(\mathrm{m}^{3} / \mathrm{kg}^{-1} \mathrm{VS}_{\mathrm{add}}{ }^{-1}\right)\end{array}$ & $\begin{array}{c}\text { Literature data }- \text { Biogas yield } \\
\left(\mathrm{m}^{3} / \mathrm{kg} \text { of } \mathrm{VS}_{\mathrm{add}}{ }^{-1}\right)\end{array}$ \\
& $0.10(\mathrm{ALVAREZ} \&$ LIDEN, 2009) \\
$\mathrm{Dl}-5.0 \%-0.42^{1}$ & 0.11 (SAEV et al. 2009) \\
& 0.15 (AMARAL et al. 2004)
\end{tabular}

Treatment: Cattle manure pre-treated with $5 \%$ of dolomite limestone

Biogas yield per $\mathrm{kg}$ of $\mathrm{VS}_{\mathrm{add}}^{-1}$ from treatment Dl-5.0\% was 78.0; 73.9 and $64.5 \%$ higher compared to findings from Alvarez \& Liden, (2009); Saev et al. (2009) and Amaral et al. (2004), respectively.

Despite of the fact that $5.0 \%$ of dolomite limestone as pre-treatment for 10 days incremented the biogas production and the biogas yield per $\mathrm{kg}$ of waste in 31.5 and $31.6 \%$ respectively, to decide if it

\section{CONCLUSION}

Chemical pre-treatment improves biogas yield in terms of $\mathrm{m}^{3} / \mathrm{kg}^{-1}$ of waste. In the scenario that this assay was carried out, the use of $5.0 \%$ of dolomite limestone is suitable to use dolomite limestone as chemical substance to pre-treat cattle manure, it is important to perform an economic analysis taking into account the amount and price of the chemical substance; amount of waste and volatile solids added into the system, and the concentration $(\%)$ of methane generated by each treatment as it shows the calorific potential value of them to generate energy.

as pre-treatment for 10 days incremented the biogas production and the biogas yield per $\mathrm{kg}$ of waste in 31.6 and $31.5 \%$, respectively. 


\section{ACKNOWLEDGMENTS}

The authors are grateful for the financial support of the Fundação de Apoio ao Desenvolvimento do Ensino, Ciência e

\section{REFERENCES}

APHA, AWWA, WPCF. Standard Methods for the Examination of Water and Wastewater $22^{\text {nd }}$ edition, American Public Health Association, Washington D.C.2012.

ALVAREZ, R.; LIDÉN, G. Low temperature anaerobic digestion of mixtures of llama, cow and sheep manure for improved methane production. Biomass and Bioenergy, v. 33 (3): 527533, 2009.

AMARAL, C.M.C.; AMARAL, L.A.; LUCAS JÚNIOR, J.; NASCIMENTO, A.A.; FERREIRA, D.S.; MACHADO, M.R.F. Biodigestão anaeróbia de dejetos de bovinos leiteiros submetidos a diferentes tempos de retenção hidráulica. Ciência Rural, v. 34 (6): 1.897-1.902, 2004.

ANDRADE, W. R.; SANTOS, T. M. B ; VASO, L. M. Monitoramento do $\mathrm{pH}$ de dejeto bovino pré-tratado com reagente ácido e alcalino. In: Encontro de Ensino, Pesquisa e Extensão - ENEPEX, 2016, Dourados - MS. ENEPEX, 2016 a.

ANDRADE, W. R.; COCA, F. G. C.; ROHOD, R.; XAVIER, C. A. N.; SANTOS, T. M. B. Produção de biogás por dejetos de ovinos submetidos a três pré-tratamentos químicos. XLV Congresso Brasileiro de Engenharia Agrícola - CONBEA 2016, Florianópolis - SC, Brasil, 2016 b.

ANGELIDAKI, I.; AHRING, B. K. Methods for increasing the biogas potential from the recalcitrant organic matter contained in manure. Water Science Technology, v.41 (4): 189-194, 2000.

BERTOZZO, F. Co-digestão anaeróbia
Tecnologia do Estado de Mato Grosso do Sul (FUNDECT), CNPq and CAPES.

de dejetos de bovinos e dois tipos de glicerina bruta. Tese (Doutorado em Agronomia), Área de concentração Energia na Agricultura, Faculdade de Ciências Agronômicas da UNESP - Campus de Botucatu, Botucatu, SP. 2013. 92p.

BRUNI, E.; JENSEN, A. P.; ANGELIDAKI, I. Comparative study of mechanical, hydrothermal, chemical and enzymatic treatments of digested biofibers to improve biogas production. Bioresource technology, v.101 (22): 8713-8720, 2010.

CARRERE, H.; ANTONOPOULOU, G., AFFES, R.; PASSOS, F.; BATTIMELLI, A.; LYBERATOS, G.; FERRER, I. Review of feedstock pre-treatment strategies for improved anaerobic digestion: From lab-scale research to fullscale application. Bioresource technology, v.199: 386-397, 2016.

CARVALHO, A.M.X.; MENDES, F.Q. SPEED Stat: a minimalist and intuitive spreadsheet program for classical experimental statistics. Anais da $62^{\mathrm{a}}$ Reunião Anual da Região Brasileira da Sociedade Internacional de Biometria, 2017. 333pp.

ČATER, M.; ZOREC, M.; LOGAR, R. M. Methods for Improving Anaerobic Lignocellulosic Substrates Degradation for Enhanced Biogas Production. Springer Science Reviews, v.2 (1): 51-61, 2014.

CHOONG, Y. Y.; NORLI, I.; ABDULLAH, A. Z.; YHAYA, M. F. Impacts of trace element supplementation on the performance of anaerobic digestion process: A critical review, Bioresource technology, v. 209: 369-379, 2016 
DIAS, T.; FRAGOSO, R.; DUARTE, E. Anaerobic co-digestion of dairy cattle manure and pear waste. Bioresource technology, v.31 (164): 420-423, 2014.

ENNOURI, H.; MILADI, B.; DIAZ, S. Z.; GÜELFO, L. A. F.; SOLERA, R., HAMDI, M.; BOUALLAGUI, H. Effect of thermal pre-treatment on the biogas production and microbial communities balance during anaerobic digestion of urban and industrial waste activated sludge. Bioresource technology, v.214: 184-191, 2016.

HE, Y.; PANG, Y.; LIU, Y.; LI, X.; WANG, K. Physicochemical characterization of rice straw pre-treated with sodium hydroxide in the solid state for enhancing biogas production. Energy \& Fuels, v. 22 (4): 2775-2781, 2008.

KUMAR, P.; BARRETT, D. M.; DELWICHE, M. J.; STROEVE, P. Methods for pre-treatment of lignocellulosic biomass for efficient hydrolysis and biofuel production. Industrial \& Engineering Chemistry Research, v.48: 3713-3729, 2009.

MAO, C.; FENG, Y.; WANG, X.; \& REN, G. Review on research achievements of biogas from anaerobic digestion. Renewable and Sustainable Energy Reviews, v.45: 540-555, 2015.

MATOS, C.F.; PAES, J.L.; PINHEIRO, É.F.; DE CAMPOS, D.V. Biogas production from dairy cattle manure, under organic and conventional production systems. Engenharia Agrícola, v.37 (6): 1081-1090, 2017.

MIRZA, U. K.; AHMAD, N.; MAJEED, T. An overview of biomass energy utilization in Pakistan. Renewable and Sustainable Energy Reviews, v.12 (3): 1988-1996, 2008.

PANEPINTO, D.; GENON, G. Analysis of the extrusion as a pre-treatment for the anaerobic digestion process. Industrial Crops and Products, v.83: 206-212, 2016.

PIÑAS, J. A. V.; VENTURINI, O. J.; LORA, E. E. S.; ROALCABA, O. D. C. Technical assessment of mono-digestion and co-digestion systems for the production of biogas from anaerobic digestion in Brazil. Renewable Energy, v.117: 447-458. 2018.

RAYCHAUDHURI, A.; GHOSH, S. K. Biomass Supply Chain in Asian and European Countries. Procedia Environmental Sciences, v.35: 914-924, 2016.

RODRÍGUEZ-MONROY, C.; MÁRMOLACITORES, G.; \& NILSSONCIFUENTES, G. Electricity generation in Chile using non-conventional renewable energy sources-A focus on biomass. Renewable and Sustainable Energy Reviews, v.81: 937-945, 2018.

SAADY, N. M; MASSÉ, D.I. A start-up of psychrophilic anaerobic sequence batch reactor digesting a 35\% total solids feed of dairy manure and wheat straw. AMB Express, v.5 (1): 144-154. 2015.

SAEV, M. B.; KOUMANOVA. I. V.; SIMEONOV. M. Anaerobic co-digestion of wasted tomatoes and cattle dung for biogas production. Journal of the University of Chemical Technology and Metallurgy, v.44 (1): p.55-60, 2009.

SANTOS, T.; TREVIZAN, P. S.; XAVIER, C. A.; KIEFER, C.; \& FERRAZ, A. L. Anaerobic biodigestion of manure from finishing pig supplemented with ractopamine over different periods. Engenharia Agrícola, v.36: 399-407, 2016.

SAWATDEENARUNAT, $\quad$ C.; SURENDRA, K. C.; TAKARA, D., OECHSNER, H., KHANAL, S. K. Anaerobic digestion of lignocellulosic biomass: Challenges and opportunities. 
Bioresource technology, v. 178: 178-186, 2015.

SURENDRA， K. C.; TAKARA， D.; JASINSKI, J.; KUMAR KHANAL，S. Household anaerobic digester for bioenergy production in developing countries: opportunities and challenges. Environmental

technology, v.34: 1671-1689, 2013.

VANHOLME, R.; DEMEDTS, B; MORREEL, K.; RALPH, J.; BOERJAN W. Lignin biosynthesis and structure. Plant Physiology, v.153: 895-905, 2010.

XAVIER, C. A. N., SANTOS, T. M. B., \& LUCAS JÚNIOR, J. Digestão anaeróbia de dejetos de bovinos leiteiros: efeito da dieta e da adição de caldo de cana-de-açúcar. Archivos de zootecnia, v.65 (250): 2016.

WANG, M., ZHANG, Y., YAN, S., YI, B., NIU, W., YUAN, Q. Enhanced Biogas Yield of Chinese Herbal Medicine Extraction Residue by Hydrothermal Pretreatment. Bio Resources, v.12: 46274638, 2017.

ZHENG, Y.; ZHAO, J.; XU, F.; \& LI, Y. Pre-treatment of lignocellulosic biomass for enhanced biogas production. Progress in Energy and Combustion Science, v. 42: 35-53, 2014. 